\title{
African Complicity in Slavery and Psychological Vexation: A Study of Caryl Phillips's Fiction
}

\author{
Jose Varunny M. \\ PhD Research Scholar, Department of English, Research Center, St. Thomas' College, Thrissur, \\ University of Calicut, Kerala, India
}

\begin{abstract}
Transatlantic slavery and its repercussions on the lives of its victims and its perpetrators alike have been some of the significant concerns of the postcolonial studies. Transatlantic slavery has been considered as one of the major colonial projects in which the dignity and rights of millions of Africans have been violated unscrupulously. As these facts are acknowledged and accepted across the world, a vast amount of accusation and condemnation are also directed against the West for inflicting such pains on humanity. However, the realization that transatlantic slavery could not have happened without the active participation of Africans compels one to examine their almost equal responsibility more seriously. Caryl Phillips (1958- ), one of the contemporary postcolonial writers in his fictional works recaptures these moments of complicity of Africans. His two novels Higher Ground and Crossing the River not only examine the African responsibility in transatlantic slavery, but also investigate how such involvement has constructed particular psychological vexation in its partakers. It allows him to see how Africans suffer physically and mentally owing to the brutal victimization under slavery, while it also significantly providing a mirror into the psyche of Africans who have collaborated with the Europeans in victimizing one's own people in transatlantic slavery. While for many this difficult truth is hard to accept and reluctant to acknowledge, for Phillips the remembrance and acknowledgement of them are some of the essential means of a cure for the psychological damage that the transatlantic slavery has created.
\end{abstract}

Key Words: African Complicity, Caryl Phillips, Crossing the River, Higher Ground, Postcolonial, Transatlantic slavery

\section{Introduction}

Transatlantic slavery readily evokes the images of brutal incursions of the Europeans on the African coasts, the traumatic journeys carrying the Africans across the Atlantic known as Middle Passage and bartering them like goods across the Atlantic. Transatlantic slavery as an institutionalized structure of oppression is reckoned to have flourished during the period from fifteenth to the nineteenth century and it was mainly built upon the need for a low-priced source of labor for sugar plantations in the Americas and elsewhere. This economic necessity of Europeans in turn shattered the lives of millions, their cultures and their hopes. Although slavery is an institution as old as humanity itself, the transatlantic slave trade, which gained momentum after the first human cargo of kidnapped Africans arrived in Portugal in 1441, gave a new meaning to the trade in humans [1]. Studies in these fields shockingly disclose that from fifteenth to nineteenth centuries, Europe's imperial powers transported between 9 and 15 million Africans to the Americas [2]. However, not only does the institution of slavery evoke memories of suffering and pain of millions of Africans, but it also leaves open the questions of agency, complicity, and historical responsibility for inflicting such cruelty on humanity. However, a significant aspect of the above spectrum of images about transatlantic slavery is that it leaves out conveniently the images of Africans selling their own people to Europeans and thus collaborating with the European slave business.

Despite the fact that slave traders from Portuguese, England, France and Spain are considered to have definite and crucial roles in perpetuating slavery and creating miserable life to millions of Africans, it is often forgotten, probably due to a sympathetic attachment felt for the African victims, that African social systems and structures too have been instrumental in enslaving the Africans and selling them to European slave traders. The recent studies have opened up new venues for more discussions and even more controversies on the subject. They have unveiled the "hard truths" about the fundamental responsibility also of Africans in the transatlantic slave trade, and thus about the complicit role of Africans in the resulting history of transatlantic slavery. For example, in the studies conducted by John Thornton and Henry Louis Gates Jr. the issue of African complicity in the transatlantic slavery has gained significant attention. Their studies dispense the myths that Africans were only the passive victims in the slave trade, or that African societies were forced into the slave business, or that the transatlantic slavery has left behind a legacy of devastation in social and economic spheres. John Thornton in his studies Africa and Africans in the Making of the Atlantic World, 1400-1680 (1992) challenges our 
received versions of stories about African history and culture during and after fifteenth century, thereby emphasizing the African culpability in transatlantic slavery. In his celebrated television/book series Wonders of the African World (1999) Henry Louis Gates Jr., a professor at Harvard presents a visually striking expedition across Africa, its history and its forgotten past. In his study, Gates invites one's attention to the history of the enslavement of millions of Africans simultaneously pointing to the African culpability in transatlantic slavery. What transpires in the above studies is that such collaborative roles played by the Africans in selling out their own people have been an undeniable outcome of African social, political and economic structures and designs. However, the present study concerns how Caryl Phillips, in his fictional works recaptures these moments of complicity. Phillips in his novels, while journeying through the labyrinths of the history of African slavery, their suffering and pain, also stops resolutely to direct readers' attention to a significant aspect of Africans' psychological torment due to their complicit act in transatlantic slave trade. More particularly, his concern is the sense of isolation, shame and guilt of the Africans in creating such massive amount of trauma for one's own people.

Caryl Phillips was born in St Kitts, one of the Caribbean islands in 1958. Weeks after his birth he was taken to Leeds by his parents and was brought up there. Living in New York City now, he is the editor of two anthologies and has written extensively for television, radio, theatre and cinema and is the author of three works of non-fiction and ten novels. As a prolific writer, his works have been recognized by numerous awards including Martin Luther King Memorial Prize, a Guggenheim Fellowship, and the 2004 Commonwealth Writers' Prize Best Book award for A Distant Shore. More importantly, Crossing the River was shortlisted for the 1993 Booker Prize. His literary commitment encompasses his much professed task of "retrieving the history". Renee T. Schatteman notes, "The driving forces behind Phillips's writing seem to be his commitment to the reworking of history to reveal new layers of analysis about the past" [3]. Phillips's writing, therefore, becomes a digging deep into the labyrinths of history, a corrective exercise and revision of history as well. He has tackled themes on the African slave trade, African diaspora and its contemporary repercussions on the lives of its descendant from various angles in addition to issues of migration in the present-day world. Essentially, the present study focuses on one of the significant moments of African slavery and slave trade. While in popular understanding, the perpetrators of transatlantic slavery are Europeans, Caryl Phillips's portrayal of African complicity brings home Africans' equal involvement in perpetuating the suffering to their people and further, his focus is not specifically on the material act of African involvement, but rather on the resultant sense of psychological distress that they encounter thereupon. Such a venture by Phillips pointedly digs up certain areas of African history that most often are sent into oblivion. Therefore, this study examines in Higher Ground (1989) and Crossing the River (1993) Africans' complicit role through the story of an unnamed collaborationist and through the voice of an African farther who sells his three children to European slaver and who achieves a mythical stature due to his ability to transcend beyond the space and time thereby sustaining this issue ever vibrant. Phillips's attempts to delineate the forgotten aspect of this African history enable us to see the drama of African complicity in transatlantic slave trade more closely and vividly.

\section{African Social Structure and Complicity in Slavery}

John Thornton's study Africa and Africans in the Making of the Atlantic World, 1400-1680 focuses on the social, political and economic structure of pre-colonial Africa and sees how they were integral to the growth and development of transatlantic slavery. Arlene Torres in a review of the book notes, "By concentrating on African social structure and the political alliances and economic ventures of the African elite, he raises important questions regarding the development of the slave trade" [4]. African social system and political structure had a lot to do with their involvement in the transatlantic slave trade. Very often African communities were diametrically opposed in nature and character. Notably, fifteenth-century African society was not homogenous in nature and character. At the time of European contact, Africa's diverse social and political structures such as those of the rule of kings and village chiefs allowed them to gain from the enslavement of their adversaries and those outside from their clans and tribes. However, within Africa, slaves were very often not held for the primary purpose of producing export commodities, but these captives were used by the kings and tribal leaders in the agricultural productions of their state.

According to John Thornton "Slavery was widespread and indigenous in African society, as was, naturally enough, a commerce in slaves. Europeans simply tapped this existing market, and Africans responded to the increased demand over the centuries by providing more slaves" [5]. Anne C. Bailey's study reveals that Africa was one continent having numerous communities large and small opposed to each other. She says that before the onset of the transatlantic slave trade in the fifteenth century and through much of the ensuing centuries, the many regions of Africa though interconnected by trade, the spread of religion, and constant intercontinental migration, these regions and communities were largely distinct and separate from one another [6]. These separate identities and community behavioral patterns have been instrumental in keeping them always on tension. The more they were aware of their oneness within the clans or tribes, the more they tried to exclude 
others. Bailey notes "though the concept of clan and kinship networks has the appearance of being inclusive, it paradoxically is also a way of excluding others" [7]. The above observations explicate that though transatlantic slavery is considered to have started with the arrival of the Europeans, the system of "slavery" within such diverse communities had existed even before their arrival. Toyin Falola and Amanda Warnock in their introduction to Encyclopedia of the Middle Passage observe that wars, raids, kidnappings, and the collection of tribute payments led to the enslavement and sale of millions of men, women, and children within African continent [8]. Such forms of slavery were combined with clientage, pawnship, debt bondage, and apprenticeship. This tradition of slavery, in fact helped to shape the involvement of African kings and leaders in the transatlantic slave trade. Thornton observes,

Slavery was widespread in Africa, and its growth and development were largely independent of the Atlantic trade, except that insofar as the Atlantic commerce stimulated internal commerce and development it also led to more widespread holding of slaves. The Atlantic slave trade was the outgrowth of this internal slavery.....the slave trade (and the Atlantic trade in general) should not be seen as an "impact" brought in from outside and functioning as some sort of autonomous factor in African history. Instead, it grew out of and was rationalized by the African societies who participated in it and had complete control over it until the slaves were loaded onto European ships for transfer to Atlantic societies. [9]

Henry Louis Gates Jr., notes, "The historians John Thornton and Linda Heywood of Boston University estimate that 90 percent of those shipped to the New World were enslaved by Africans and then sold to European traders. The sad truth is that without complex business partnerships between African elites and European traders and commercial agents, the slave trade to the New World would have been impossible, at least on the scale it occurred" [10]. The above facts open up new dimension to the study of African slavery that it indicates two different sources of exploitation that sustained transatlantic slavery. Anne C. Bailey observes, "The fact of the dual involvement of Europeans and Africans in the slave trade did not imply equal partnership but rather parallel lines of activity originating from different cultural and political spaces [11]. Bailey's observation suggests that varied socio-cultural background of Africa that contributed and accelerated transatlantic slave trade were some of the different sources of operations along the lines of European involvement in transatlantic slavery.

\section{Psychological Vexation of African Collaborationist in Higher Ground}

The first section "Heartland" in Phillips's novel Higher Ground takes the readers to the time of transatlantic slavery during the period of 1800 's. Phillips's attempt here is to redirect the attention of readers to the psychological dynamics of Africans who have involved in the slave trade. The unnamed collaborationist is an African caught by his native king's men and is taught the colonizer's language. Due to his linguistic capabilities, he is appointed as an intermediary of an English slaving expedition to conduct the trade as safely and efficiently as possible. Anne C. Bailey points out that generally, the European and American slavers through their artful strategies and tactful relations maneuvered systematic modes of operation in the slave business to gain acceptance and approval of the local tribes and leaders. One of such components was employing the locals to assist them on the coast as canoe men, servants, messengers, gong beaters, washerwomen, porters, and translators [12]. The collaborationist in the novel has been assigned with such a role and his problem is that his position is one that is thrust upon him. Working as a translator and facilitator between the captives and the captors he has avoided being sold as a slave to the white slavers but he also becomes simultaneously a victim and victimizer. However, he despises his present position as a collaborator in the slave trade, and later on, having fallen in love with a young village girl who has been abused by her captors, he is doomed to descend from his privileged position to the level of a dehumanized slave. Throughout the story Phillips demonstrates the collaborator's psychological anguish in participating with the whites in slave trade and in distancing himself from his own people.

Essentially, the section 'Heartland' sheds light on African responsibility in transatlantic slavery. It not only exposes the role of collaborationist, rather it places explicit statements about the role of the village Head Man and his people. One of the significant aspects that Phillips highlights in his novels is that slavery as a colonial system is backed up by the African chiefs and heads. Phillips's writing reveals the casualness of the African tribal leaders and their hypocritical pretensions in delivering their own people to slavery. In what he says, "Some years ago a king's trader captured me and sold me to one of their factors" [13], he blames the social system in which he finds the African leaders' collaboration with the slavers. For the African tribal leaders and elites, the slaves formed their "property' that brought them a substantial amount of income. Thornton examines, "Slavery was widespread in Atlantic Africa because slaves were the only form of private, revenue-producing property recognized in African law" [14]. The idea that the business in human cargo has thrived in the village is clear from the observation that the collaborationist makes. He suggests that the villages are empty of young men, presumably captured by local kings and tribal leaders, and the future of young children seems to be bleak as they are brought up to be sold out as slaves later on. He surveys the situation at the village. "The village is 
denuded. It contains mainly women and old men, with a few children (the seedlings) running wild. They will soon blossom into the young exportable goods of this trading continent" [15] When the elders of the village blame him for what he is doing, he reflects on their complicit roles in selling out their own people. He feels "Why do they seem intent upon blaming me? Have I, unlike their Head Man, ever made profit for myself? ... But observe the price of their treachery. Their sons and daughters are gone from them for ever" [16]. Even though the collaborationist has not been willingly complicit in the business, the village-elders hold him responsible for inflicting pain and loss to the village.

Various instances in the section of novel explain the culpability of Africans and at the same time their eagerness to disown it. On one occasion while exposing the debauchery of the kings and rulers of Africa, the Governor, one of the European slavers, holds them in contempt for their mean business in slave trade. His analysis exposes a true picture of society. He says,

I am led to believe that certain chiefs have been known to raid their own villages and seize people of customs, language, and manners near to their own, then subject them to their whims of factors in exchange for brandy. Imagine being able to pay a king or chief in alcohol to round up his own people and reduce them to little more than horses tied to posts.... Bells, baubles, bars of lead, beer, such things sway the minds of your so-called leaders and they willingly aid in this business. [17]

With the recognition and acknowledgement of the existence of African responsibility come the immediate responses from the Africans themselves to disown it or transfer the responsibility onto somebody else. Caryl Phillips brings in these psychological states of the African rulers or leaders for discussion and unlocks their guilt-laden conscience in different ways. The collaborationist while trying to sort out his own position in the whole business of slave trade finds the village Elders holding him responsible for their present misery. But what surprises him most is the enthusiasm with which they try to accuse him by transferring the whole responsibility on to the shoulders of the collaborationist. The vigorous accusation leveled against him appears to be a means of disowning the responsibility that the African leaders shoulder on. "I set the circumstances of my existence against those of these Elders and I laugh. They are able to justify their way of life by pointing to people like myself whom they consider guilty of a greater betrayal. But observe the price of their treachery. Their sons and daughters are gone from them forever" [18]. However, in a close analysis, one may find also the collaborationist with certain amount of complicity. He is a close aide for the white slavers in enslaving his own people. Even though, he feels that his position is thrust upon him, what becomes clear is that he does not attempt to extricate himself from such position, for in that position he finds safety and security from being sold out. Psychologically the collaborator feels somehow secure within the position proffered to him. He says, "Within the confines of the Fort my position is secure, if low and often unbearable. I now find it difficult to conceive of a life either before or after this place" [19]. But, had he had true regret over the actions that he had been doing with the white slavers he would have escaped the job and "freed" himself of the "burden." $\mathrm{He}$ exhibits such kind of strength of character towards the end when he knows that the girl whom he loves is molested by the slavers. But the price that he pays for that is to quit his safe position as a collaborator. In fact, at the end he frees himself from the "clutches" that has bound him hitherto.

Caryl Phillips focuses on a particular psychological disposition that the collaborationist develops after he takes up his job with the white slavers. He is situated in a predicament, in which he finds himself alienated from his own community as they consider him participating with the whites. Believing to be part of a society but not being accepted by it makes his situation complicated and his psyche even more fractured. He laments, "I have cut myself off from these villagers to such an extent that I have actually become their enemy" [20]. This sense of being away from his folks, distances him both physically and psychologically. He feels, "They blame me because I am easily identifiable as one who dwells with the enemy" [21]. The European colonial discourses that are instilled by the colonial slavers like Governor on collaborationist are intended to widen the gap between him and his people. This is a colonial strategy, which facilitates their "economic necessity" go smoothly. His understanding that he stands despised both by his own people for his role as a collaborationist and by the British for his complicit role in doing a business in slaves, makes his suffering more acute and poignant. He reads the implication of their stare when standing in the village with Price to ask for the girl.

They stare back at my clothes and Price's person with similar disdain. It is moments such as these that I loathe. Marooned between them, knowing that neither fully trusts me, that neither wants to be close to me, neither recognizes my smell or my posture, it is only in such situations that the magnitude of my fall strikes me. I want to run. [22]

With the privilege of his linguistic capabilities, he is not recognized as an equal even among the white captors because racial stereotypes have been sustained to maintain dissimilarity between them. Therefore, he finds himself isolated from his people and the white slavers for whom he works as well. As a result a sense of isolation and loneliness overpowers him and cripples his psychic saneness. His cry is, "Loneliness scales the walls of my being and threatens to destroy my soul. Her assaults are increasingly difficult to withstand. Have all Gods abandoned me?" [23] Precisely, what worries him most is his severing the relationship with the 
community and their finding him guilty. As a man expected to become a village chief one day, his fall has been immense. By collaborating with the white slavers he gained nothing, but remains a lonely and isolated, cut off from his family, community and his own self. His acceptance to the village community remains closed forever due to his assumed complicit role. A sense of shame and disgrace overpowers him when he realizes that his privileged position is a detested one and it is achieved at the cost of his own people.

However, due to his complicit role, the collaborationist also experiences acute sense of powerlessness. In quite a few places, he confesses his powerlessness and inability so poignantly to react against the situations that it demands him to do. He says, "I ... am expected to be something other than I am" [24]. When the village elder holds the collaborationist in contempt for what he does and spits on his face saying, "you are filth," he, "wipe[s] away the spittle and choose[s] not to retaliate" [25]. Yet, on another occasion, he tells the girl who has been molested by Price that "I could not help you because I was frightened" [26] and while recalling his inability to rescue the girl, he understands, "I am powerless to help" [27]. To some degree, the powerlessness felt by the collaborationist stems from two sources; first, from the fear of violence and degradation that are likely to follow the resistance, and second, he fears a rupture in the intimacy and the temporary privilege attached to his position. However, these strictures keep him psychologically distressed and worried until a moment he makes a qualitative resistance.

\section{The Guilt-laden African father in Crossing the River}

Crossing the River juxtaposes various moments of transatlantic slavery from its origin on the African coast, African complicity and the dispersal of the blacks across the globe. It is an explication of a "... sophisticated, sometimes-sorrowful meditation upon the painful dislocations, longings and 'weird' relationships borne of the aptly named 'peculiar institution' of slavery" [28]. The entire narrative is fitted in to the framework of a guilt-laden conscience of a mythical African father who sells his three children (two boys and one girl) following the failure of the crops. The African father and his three children become the archetypal images for Africa and its people respectively. Phillips's literary technique is highly commendable here, for he brings the whole gamut of African complicity in a couple of lines which the African father speaks. "A desperate foolishness. The crops failed. I sold my children. I remember" [29]. Here African father's motive behind selling his children, his confession of his complicity and his deep seated remorse on that act and above all his remembrance of the act after two hundred and fifty years after his complicit act that has initiated an eternal diaspora of his descendents, are all evident. Phillips places the African father and his children beyond particular space and time. According to Yogita Goyal, Africa within this particular context does not possess a contemporary existence. Guilt-ridden due to its complicity, it is cast outside history and time, ossified in the primal moment, birthing the diaspora through this act of betrayal [30].

The prologue tells the history of transatlantic slavery and it explains how they regret upon such complicity. The sense of guilt and remorse that the African father express as is informed, originates at the "shameful intercourse" of bartering the African children, "their warm flesh" exchanged for cold goods and the desperate realization that "their lives fractured" [31]. The African father who stands for every African who has participated in transatlantic slave trade realizes the nature of his business as "shameful intercourse". It is a sign of recognition and acknowledgement of his complicity in selling out "warm flesh", his children. The lines "A desperate foolishness. The crops failed. I sold my children" [32] explain the reason for the sale of African children over the centuries. It recalls one's attention to the system of bartering of Africans for European goods and the insignificance that they feel about it. The mythical father figure experiences a sense of shame and dishonour in selling out his own children to the slave owner thereby scattering them across the globe. And the children remain cut off from their roots forever, as there is "No sign posts. There is no return. To a land trampled by the muddy boots of others. To a people encouraged to war among themselves. To a father consumed with guilt" [33]. Their fate is sealed when he says that "You are beyond. Broken-off, like limbs from a tree" [34]. This cry of the African father typifies the nature of displacement and diaspora through which each displaced African has to travel and survive finally. According to Goyal it is neither the memory of slavery that brings these descendants together, nor suffering nor the experience of the middle passage, nor a qualified access to modernity, nor double consciousness rather it is the simple fact of being born in Africa [35].

However, the memory that haunts the African father is the 'common memory' of complicity that characterises the African collaborators in the transatlantic slavery. Though a very short remembrance by the mythical African father, it importantly sheds light on the responsibility of the Africans in creating such massive scale of trauma and pain for its own people. By unwrapping the collective unconscious of the Africans through the voice of African father, what Phillips intends to do is to keep vibrant across time and space the question of African agency and the resultant psychological havoc emerging out of it. It unsettles the minds of the Africans, inevitably questions the moral obligation for the trauma enforced upon millions of Africans. It is a constant reminder for the Africans while recounting the miseries and pains inflicted by the Europeans on them through a system of slave trade and slavery. What the Governor in Higher Ground observes is indicative of a constant 
reminder and remainder of such complicity. "But your people, it is possible you may never recover from this intrusion" [36].

\section{Conclusion}

Taking his fictional characters through the complex maze of psychic dynamics, Phillips unravels the fundamental psychological effects of African's complicity in transatlantic slavery. This involvement of the Africans in constituting the transatlantic slave trade and slavery has raised certain important moral questions about the whole issue of the system of slavery. "Why did Africans sell other Africans into slavery? It is a vexing question asked by many — not only descendants of Africa in the African Diaspora, not only historians of slavery and the slave trade - but by all who seek answers to some of the great tragedies of human history" [37]. An answer to this question inevitably awaits many reconciliatory processes. An excerpt from the Diary entries on the slave trade which appears in Wonders of the African World by Henry Louis Gates, Jr., reads as follows: "Slavery, we know, has left a hole in the hearts of African Americans. But it has also had the most devastating effects on the African societies left behind. Does this legacy haunt Africa today? For even while guilt itself is not heritable, could it be that the consequences of that guilt somehow persist? How can a society expiate such sins of the fathers? These are the thoughts, this is the despair, that I suppress when thinking about the history of the slave trade, and the centrality of black African involvement in it" [38]. Phillips study reveals that Africa cannot disown this complicity as it has become a part of its history and therefore, it stands compellingly facing the history to examine its own conscience simultaneously suffering from guilt and remorse.

\section{References}

[1] M. Logan, African wars, in Toyin Falola and Amanda Warnock (Ed) Encyclopedia of the Middle Passage, (Westport-London: Greenwood Press, 2007) 393-396.

[2] T. Falola and Amanda, Introduction, in Toyin Falola and Amanda Warnock (Ed) Encyclopedia of the Middle Passage, (WestportLondon: Greenwood Press, 2007) xv-xxvii.

[3] R. T. Schatteman. Introduction, in Renee T. Schatteman (Ed) Conversations with Caryl Phillips, (Jackson USA: University Press of Mississippi, 2009) ix-xviii.

[4] A. Torres, Africa and Africans in the making of the Atlantic world, 1400-1680, American Anthropologist 95(1), 1993, 229-230.

[5] J. Thornton, Africa and Africans in the Making of the Atlantic World, 1400-1680 (Cambridge: Cambridge University Press, 1992).

[6] A. C. Bailey, African voices of the Atlantic slave trade: Beyond the silence and the shame, (Boston: Beacon Press, 2005)

[7] A. C. Bailey, African voices of the Atlantic slave trade: Beyond the silence and the shame, (Boston: Beacon Press, 2005)

[8] T. Falola and A. Warnock, Introduction, in Toyin Falola and Amanda Warnock (Ed) Encyclopedia of the Middle Passage, (WestportLondon: Greenwood Press, 2007) xv-xxvii.

[9] J. Thornton, Africa and Africans in the Making of the Atlantic World, 1400-1680 (Cambridge: Cambridge University Press, 1992).

[10] H.L. Gates Jr., Ending the slavery blame-game, The New York Times, 10 April 2010, http://www.nytimes.com/2010/04/23/opinion/23gates.html?_r=0, Accessed on 20 June 2013.

[11] A. C. Bailey, African voices of the Atlantic slave trade: Beyond the silence and the shame, (Boston: Beacon Press, 2005)

[12] A. C. Bailey, African voices of the Atlantic slave trade: Beyond the silence and the shame, (Boston: Beacon Press, 2005)

[13] C. Phillips, Higher Ground,(New York: Vintage, 1989).

[14] J. Thornton, Africa and Africans in the Making of the Atlantic World, 1400-1680 (Cambridge: Cambridge University Press, 1992).

[15] C. Phillips, Higher Ground, (New York: Vintage, 1989).

[16] C. Phillips, Higher Ground, (New York: Vintage, 1989).

[17] C. Phillips, Higher Ground, (New York: Vintage, 1989).

[18] C. Phillips, Higher Ground, (New York: Vintage, 1989).

[19] C. Phillips, Higher Ground, (New York: Vintage, 1989).

[20] C. Phillips, Higher Ground, (New York: Vintage, 1989).

[21] C. Phillips, Higher Ground, (New York: Vintage, 1989).

[22] C. Phillips, Higher Ground, (New York: Vintage, 1989).

[23] C. Phillips, Higher Ground, ( New York: Vintage, 1989).

[24] C. Phillips, Higher Ground,( New York: Vintage, 1989).

[25] C. Phillips, Higher Ground, (New York: Vintage, 1989).

[26] C. Phillips, Higher Ground, (New York: Vintage, 1989).

[27] C. Phillips, Higher Ground, ( New York: Vintage, 1989).

[28] C.M. Davison, Crisscrossing the river: An interview with Caryl Phillips, in Renee T. Schatteman. (Ed) Conversations with Caryl Phillips, (Jackson USA: University Press of Mississippi, 2009) 19-26.

[29] C. Phillips, Crossing the River, (New York: Vintage, 1993)

[30] Y. Goyal, Theorizing Africa in black diaspora studies: Caryl Phillips's Crossing the River. Diaspora 12(1), 2003, 5-38.

[31] C. Phillips, Crossing the River, (New York: Vintage, 1993)

[32] C. Phillips, Crossing the River (New York: Vintage, 1993)

[33] C. Phillips, Crossing the River (New York: Vintage, 1993)

[34] C. Phillips, Crossing the River, (New York: Vintage, 1993)

[35] Y. Goyal, Theorizing Africa in black diaspora studies: Caryl Phillips's Crossing the River. Diaspora 12(1), $2003,5-38$.

[36] C. Phillips, Higher Ground, (New York: Vintage, 1989).

[37] A. C. Bailey, African voices of the Atlantic slave trade: Beyond the silence and the shame, (Boston: Beacon Press, 2005). [38] H.L. Gates Jr., Diary: Reflections on the slave trade. http://www.pbs.org/wonders/Episodes/Epi3/3_diary1a.htm, 18 June 2013. 